\title{
Nutrigenomics in farm animals
}

\begin{abstract}
Nutrigenomics and nutrigenetics are new disciplines that study the effects of food at the genetic level. Nutrigenomics studies how bioactive chemicals in foods and supplements affects animal metabolism by altering gene expression and unites many fields: nutrition, bioinformatics, molecular biology, genomics, functional genomics, epidemiology, and epigenomics. The use of multi-disciplinary tools provides new opportunities to investigate the complex interactions of the genome and the diet. These new approaches highlight the relevant role of genetics-nutrition interactions on different physiological and metabolic processes with a high impact on economically relevant traits as meat and milk quality, and the interest of multidisciplinary studies to face these new complex issues. The objective of this mini-review is to discuss the basic concepts, technical terms and technologies involved in Nutrigenomics studies and also to discuss the results of some published works that show how nutrition affects the expression of genes involved in lipid metabolism, oxidative processes and milk production and how nutritional intervention might change meat quality and tissue composition.
\end{abstract}

Keywords: nutrigenomics, transcriptomics, gene expression, nutrition and farm animals
Volume 4 Issue I - 2017

\author{
Benítez R, Núñez Y, Óvilo C \\ Department of Mejora Genetica Animal, Spain
}

Correspondence: Cristina Óvilo, Department of Mejora Genetica Animal, INIA, Ctra de la Coruna, Km 7.528040 Madrid, Spain, Tel +3491347/492, Email ovilo@inia.es

Received: January 16, 2016 | Published: March 16, 2017
Abbreviations: PUFA, polyunsaturated fatty acid; PCR, polymerase chain reaction; DNA, deoxyribonucleic acid; RNA, ribonucleic acid; SFA, saturated fatty acid; MUFA, monounsaturated fatty acid; SCD, $\triangle 9$-desaturase; FASN, fatty acids synthase; STAT5, signal transducer and activator of transcription 5; CEBPA, ccaat/ enhancer-binding protein (alpha); CLA, conjugated linoleic acid; ACOX1, acyl-coa oxidase 1; ACSL4, acyl-coa synthetase long-chain family member 4 ; RXRG, retinoid x receptor gamma; CEBPB, ccaat/ enhancer binding protein (beta); IGF1, insulin-like growth factor 1; INSR, insulin receptor; CRABII, cellular retinoic acid binding protein 2; IMF, intramuscular Fat; VE, Vitamin E; GP, grape pomace; CAT, catalase; SCP2, sterol carrier protein 2; HADH, 3-hydroxyacyl CoA dehydrogenase; HMOX2, heme-oxygenase 2; SOD1, superoxide dismutase 1

\section{Introduction}

In recent years there has been an enormous development of molecular genetics techniques allowing the study of genome function on a large scale. These advances have been accompanied by a decrease in costs and greater accessibility, which has contributed to the development of new disciplines that would fall within the generic term "Nutritional Genomics". This nascent area studies the interactions of food and its components with the genome at the molecular, cellular and systemic levels. Nutritional Genomics is currently divided into two different fields of research: "Nutrigenomics" has emerged as a novel and multidisciplinary research field in nutritional science that aims to elucidate how dietary nutrients can interact with genes affecting transcription factors, RNA and protein expression, cellular homeostasis and metabolite production (genome, transcriptome, proteome, metabolome). In this field, many studies have been carried out in human and mouse, with the main objective to study the molecular basis of diseases such as obesity, cardiovascular diseases and cancer, understanding them as a result of gene/diet type interactions. ${ }^{1,2}$ In domestic animals these nutrigenomic studies are much less abundant and in general are focused on the study of a reduced number of genes especially related to a particular treatment, mainly referred to the energy content of the diet, or the content of some of its components: polyunsaturated fatty acids (PUFA) ${ }^{3}$ protein $^{4}$ or L-carnitine. ${ }^{5}$ "Nutrigenetics" studies how structural genetic variation affects the diet effects on phenotype. There are possibly thousands of gene polymorphisms which may result in minor deviations in nutritional biochemistry influencing the diet effects on metabolism. The ultimate objective of this applied discipline is to provide nutritional recommendations taking into account the genetic makeup of each individual, what in human nutrition is called "Personalized Nutrition". In domestic animals this discipline is practically unexplored.

Nutrigenomics plays an important role in integrating genomic approaches into nutrition research. Well over a decade ago, nutrigenomics diverged from mainstream nutritional science as a specific methodological and conceptual approach. ${ }^{6}$ Over the course of this decade, the identity of nutrigenomics as an independent field of research was firmly established sometimes in opposition to "nutrition science". So far, in animal production, nutrition and genetics have mainly been used as independent disciplines without taking into account the genome-nutrition interactions on the various physiological and metabolic processes with transcendence on phenotype and production. The interest of the nutrigenomic studies is that they allow us to deepen in the knowledge of the genes and metabolic routes affected by the diet and the influence that these nutritional interventions can have on their regulation. The objective of this mini-review is to discuss the basic concepts, technical terms and technologies involved in nutrigenomics and also discuss the results of some published studies that show how nutrition affects the expression of genes involved in metabolism and how nutritional intervention might change animal products quality and tissue composition.

\section{The technologies}

Traditionally, nutrigenomics studies have employed small-scale techniques (Northern, Differential Display PCR and quantitative real-time PCR) that measure the expression of a reduced number of genes. Actually new technologies of genomic analysis allow more powerful approaches to a variety of problems in biology. The 
study of gene expression on a large scale is possible today, thanks to the development of microarrays and massive sequencing of the transcriptome (RNAseq). These new technologies introduced the concept of high-throughput data accumulation through automation and parallelization of protein and DNA/RNA chemistries. The most widely adopted omics technologies have been the ones developed to gather transcriptomic, proteomic, and metabolomic data. Newly emerging bioinformatics techniques along with biological data generated from genomics and transcriptomics studies have already allowed biologists to apply modern systems approaches to study interactions occurring inside living systems. Nutrigenomics extends the use of these large-scale gene expression technologies to the study of the effects and interactions of diet with gene expression. The study of differentially expressed genes in animals subjected to different nutritional interventions allows to know the molecular basis of phenotypic differences observed between groups, identifying the genes and metabolic pathways directly involved in the regulation of tissue composition and therefore in their quality.

\section{Evidence of the influence of diet on gene expression} and metabolism in livestock species

The new researches into molecular interactions of dietary nutrients have indicated that gene expression is modified by a number of dietary components such as carbohydrates, proteins, fatty acids, vitamins and minerals as well as phytochemicals (flavonoids, isothicyanates, etc.). Most traits of interest for meat production have a multifactorial background, i.e., meat attributes are due to interaction between the complex genetic background and the environment, with feeding being the most decisive factor in animal production. Feeding has a regulatory effect on biological processes in muscle, which is directly reflected in the quality of the meat, among other tissues. The knowledge of the complex interaction between the individual nutrients and their interaction on the genome of farm animals, which represent $30-40,000$ genes within each species, is practically an unexplored area. The major reason for this is that the technical resources for such understanding have only become accessible within the past few years. The ongoing mapping of the genomes of the principal farm animals together with the progress within information technology and molecular biological techniques has accelerated this process. ${ }^{7}$ Several experimental approaches and interventional study designs are used in this field, and some of the typical examples and their results are discussed in the context of various aspects of meat and milk quality. Table 1 contains a summary of published work in farm animals, using nutrigenomic technologies.

Table I Applications of Nutrigenomics technologyin farm domestic animals

\begin{tabular}{|c|c|c|c|c|c|}
\hline Species & Type of analysis & Tissue & Dietary treatment & Description of the study & Reference \\
\hline Swine & $\begin{array}{l}\text { Candidate gene } \\
\text { expression }\end{array}$ & Adipose & Oleic acid & $\begin{array}{l}\text { Adipose tissue transcriptional response of lipid } \\
\text { metabolism genes in growing lberian pigs fed oleic acid v. } \\
\text { carbohydrate enriched diets. }\end{array}$ & 8 \\
\hline Swine & $\begin{array}{l}\text { Candidate gene } \\
\text { expression }\end{array}$ & $\begin{array}{l}\text { Muscle, adipose } \\
\text { and liver }\end{array}$ & SFA and PUFA & $\begin{array}{l}\text { Effects of dietary fat saturation on fatty acid composition } \\
\text { and gene transcription in different tissues of Iberian pigs. }\end{array}$ & 9 \\
\hline Swine & $\begin{array}{l}\text { Candidate gene } \\
\text { expression }\end{array}$ & $\begin{array}{l}\text { Muscle and } \\
\text { adipose }\end{array}$ & Vitamin A & $\begin{array}{l}\text { Long term vitamin A restriction improves meat quality } \\
\text { parameters and modifies gene expression in Iberian pigs. }\end{array}$ & 10 \\
\hline Swine & $\begin{array}{l}\text { Microarrays and } \\
\text { candidate gene } \\
\text { expression }\end{array}$ & $\begin{array}{l}\text { Muscle, adipose } \\
\text { and liver }\end{array}$ & Oleic acid & $\begin{array}{l}\text { Effects of dietary energy source (carbohydrates vs } \\
\text { oleic acid) on FA composition and gene transcription in } \\
\text { different tissues of Iberian pigs. }\end{array}$ & 11 \\
\hline Swine & Transcriptomics & Muscle & $\begin{array}{l}\text { Low protein } \\
\text { (I4.5\%DM) }\end{array}$ & $\begin{array}{l}\text { An extensive perturbation of overall energy metabolism } \\
\text { in muscle occurred in response to protein restriction. A } \\
\text { low protein diet can modulate intramuscular fat content } \\
\text { of muscle but negatively impacts protein synthesis } \\
\text { pathways. }\end{array}$ & 4 \\
\hline Swine & Transcriptomics & Leukocytes & Selenium & $\begin{array}{l}\text { Gene profile of selenium-fed pigs indicate a modulatory } \\
\text { effect on multiple physiological pathways. }\end{array}$ & 12 \\
\hline Swine & Proteomics & Muscle & Linoleic acid & $\begin{array}{l}\text { The proteome changes in LM contributed to greater } \\
\text { intramuscular lipid content in CLA-supplemented pigs. }\end{array}$ & 13 \\
\hline Swine & Transcriptomics & Muscle & I-Carnitine & $\begin{array}{l}\text { L-Carnitine supplementation may have beneficial } \\
\text { effects on maintaining IGF-I signaling and inhibiting the } \\
\text { expression of proapoptotic and atrophy-related genes. }\end{array}$ & 5 \\
\hline Swine & Transcriptomics & Intestine & Glutamine & $\begin{array}{l}\text { The study revealed coordinate alterations of gene } \\
\text { expression in response to weaning and aided in providing } \\
\text { molecular mechanisms for the beneficial effect of dietary } \\
\text { glutamine supplementation to improve nutrition status } \\
\text { in piglets. }\end{array}$ & 14 \\
\hline Bovine & Transcriptomics & Adipose & Level of protein & $\begin{array}{l}\text { Estimates different levels of protein supplementary diet } \\
\text { on gene expressions related to intramuscular deposition } \\
\text { in early-weaned yaks. }\end{array}$ & 15 \\
\hline
\end{tabular}


Table continued...

\begin{tabular}{|c|c|c|c|c|c|}
\hline Species & Type of analysis & Tissue & Dietary treatment & Description of the study & Reference \\
\hline Bovine & Transcriptomics & Liver & Selenium & $\begin{array}{l}\text { Dietary supplementation of selenium in inorganic } \\
\text { and organic forms alters blood and liver selenium } \\
\text { concentrations and liver gene expression profiles of } \\
\text { growing beef heifers. }\end{array}$ & 16 \\
\hline Bovine & Transcriptomics & Adipose & $\begin{array}{l}\text { Pasture with corn } \\
\text { oil vs corn grain vs } \\
\text { concentrate }\end{array}$ & $\begin{array}{l}\text { Effect of diet supplementation on the expression of } \\
\text { bovine genes associated with fatty acid synthesis and } \\
\text { metabolism. }\end{array}$ & 17 \\
\hline Bovine & Transcriptomics & Adipose & Omega-6 & $\begin{array}{l}\text { Omega- } 6 \text { fat supplementation alters lipogenic gene } \\
\text { expression in bovine subcutaneous adipose tissue }\end{array}$ & 18 \\
\hline Lambs & $\begin{array}{l}\text { Candidate gene } \\
\text { expression }\end{array}$ & Muscle & $\begin{array}{l}\text { Concentrate feeding } \\
\text { system }\end{array}$ & $\begin{array}{l}\text { Evaluate the effect of the feeding system on fatty acid } \\
\text { composition, CLA content and SCD, PPARG, PPARA } \\
\text { and SREBPI gene expression and their relationship in } \\
\text { semitendinous muscle in light lambs. }\end{array}$ & 19 \\
\hline Poultry & $\begin{array}{l}\text { Candidate gene } \\
\text { expression }\end{array}$ & Muscle & $\begin{array}{l}\text { Vitamin E and Grape } \\
\text { pomace }\end{array}$ & $\begin{array}{l}\text { Study and compare the effects of Vitamin E and Grape } \\
\text { pomace on the candidate gene expression involved in } \\
\text { oxidation and lipid metabolism. }\end{array}$ & 20 \\
\hline Poultry & Transcriptomics & Liver & Inulin & $\begin{array}{l}\text { Data support use of dietary inulin supplementation } \\
\text { as a prebiotic in place of antibiotics for improving } \\
\text { performance and immunity in poultry along with a } \\
\text { healthier meat lipid profile. }\end{array}$ & 21 \\
\hline Poultry & Transcriptomics & Muscle & Chromium picolinate & $\begin{array}{l}\text { The study provides clues on the molecular mechanism } \\
\text { of protein synthesis in skeletal muscle-related microRNA } \\
\text { with chromium picolinate supplementation. }\end{array}$ & 22 \\
\hline Poultry & Transcriptomics & Muscle & $\begin{array}{l}\text { Algae based } \\
\text { antioxidant and } \\
\text { vitamin } \mathrm{E}\end{array}$ & $\begin{array}{l}\text { Comparative transcriptomic study of vitamin } \mathrm{E} \text { and } \\
\text { an algae-based antioxidant as antioxidative agents: } \\
\text { investigation in broiler diets. }\end{array}$ & 23 \\
\hline Poultry & Transcriptomics & $\begin{array}{l}\text { Intestinal } \\
\text { lymphocyte }\end{array}$ & $\begin{array}{l}\text { Carvacrol, } \\
\text { cinnamaldehyde, } \\
\text { Capsicum or } \\
\text { oleoresin }\end{array}$ & $\begin{array}{l}\text { Results provide new information concerning the } \\
\text { molecular mechanisms involved in dietary modulation } \\
\text { of host immunity, physiology and metabolism, helping } \\
\text { the development of novel dietary strategies to } \\
\text { immunomodulate host response in normal and diseased } \\
\text { states }\end{array}$ & 25 \\
\hline
\end{tabular}

PUFA, polyunsaturated fatty acid; SFA, saturated fatty acid; FA, fatty acid; MUFA, monounsaturated fatty acid; SCD, $89-$ desaturase fatty acids; CLA, conjugated linoleic acid; IGF-I, insulin-like growth factor I; PPARG, peroxisome proliferator activated receptor gamma; PPARA, peroxisome proliferator activated receptor alpha; SREBPI, sterol regulatory binding transcription factor I

\section{Studies of supplementation with fatty acids}

Animal breeding offers the possibility to obtain improved food products. In this way, Woods and Fearon ${ }^{8}$ examined in a review the sources of fatty acids available for inclusion in animal diets and their subsequent transfer into meat, eggs or milk. The use of diets enriched in fatty acids in pig production is a possible strategy to modulate the composition of the tissues and to improve its organoleptic and technological quality. On the other hand, the control of fat composition in the pig is related to important nutritional aspects of food of animal origin and with the characteristics and technological aspects of meat and processed meat products. So far, the effort has focused on exploring the possibilities of controlling the amount and composition of lipids that are included in pig feed ${ }^{9,10}$ to try to identify the genes associated with lipid metabolism, which may modulate the genetic potential of individuals to produce different types of fat (saturated vs unsaturated), and which may have a practical interest in obtaining products with better sensory and nutritional quality. Most nutrigenomic studies in swine have employed the Iberian breed. Iberian pig is the most representative Mediterranean traditional breed, which has an important commercial value based on high quality drycured products. Iberian breed is characterized by very high lipogenic potential, high desaturation capacity and a peculiar fatty acid profile due its genetic predisposition (thrifty genotype) and feeding system (acorns and pasture). In this breed, interactions genome-nutrition are expected to have a main role on phenotype, and different diets regarding energy source and FA profile have been essayed in order to study their effects on composition and lipid metabolism in adipose, muscular and hepatic tissues. For this purpose, isoenergetic and isoproteic diets of different lipid composition were compared, supplemented with $6 \%$ high oleic sunflower oil or carbohydrates as source of energy. ${ }^{11,12}$ At the level of tissue composition, the results 
showed both the direct deposition of nutrients and also their influence on endogenous synthesis, with a higher proportion of saturated fat in carbohydrate-based fed animals, as a consequence of increase de novo lipogenesis in this group, while animals fed with high oleic diet show more monounsaturated fat in their tissues. In the analysis of the transcriptome of adipose tissue the differential expression of 37 genes was detected, indicating that the nutrients used in these diets modulate the expression of genes related to important routes of lipid metabolism, such as the concentration and oxidation of fatty acids and synthesis of prostanoids. The animals of the high oleic diet presented induction of genes involved in protection against oxidative stress and cell damage, in agreement with a potential beneficial effect of oleic acid on animal health. The results indicate small effects of diet on gene expression, and variables as a function of time, tissue and physiological status of the animal, highlighting the complexity of these regulatory effects and their study. ${ }^{11}$ On the other hand, the results of another work comparing saturated vs. polyunsaturated diets in Iberian pigs $^{13}$ indicate again that the fatty acid composition of the tissues is affected by the nutritional treatment, with a higher content of monounsaturated fatty acids and lower ratio $n-6 / n-3$ in pigs fed saturated fat and only an increase in saturated fat in adipose tissue for this diet. As for the transcriptional response to treatment, in adipose tissue, results show a lower SCD gene expression in animals fed a PUFA enriched diet, confirming previous findings supporting the inhibitory role of linoleic acid on SCD gene promoter in liver and adipose tissues. In this study, in liver, a higher response was observed, with up regulation of lipogenic genes (SCD, ACACA and ME1) in saturated fat-fed animals. This result suggests that this diet has a positive effect on lipogenesis in accordance with the composition results. These experiments have allowed to explore the physiogenetic processes that influence these tissues in the accumulation and metabolism of the different lipid fractions and therefore in the quality of the meat and the fat.

Examples of FA supplementation can also be found in ruminants. Joseph et al. ${ }^{14,15}$ studied the effects of different diet supplementations of the expression of genes involved in lipid metabolism in Angus steers. This study compared animals fed either pasture only, pasture with soybean hulls and corn oil, pasture with corn grain, or high concentrate diet. Results showed that changes in diet with increased dietary energy intake by supplementing high concentrate diet had effects on the transcription of genes encoding enzymes involved in fat metabolism, which in turn has effects on fatty acid content in the carcass tissues as well as carcass quality. Corn supplementation either as oil or grain appeared to significantly alter the expression of genes directly associated with fatty acid synthesis. In the comparison between concentrate and pasture, FASN and SCD genes were up regulated and STAT5 and CEBPA genes were down regulated in concentrate diet, while the comparison between corn oil and pasture with respect to pasture didn't show significant effects. In the comparison between corn grain and pasture with respect to pasture, FASN and SCD genes were unregulated in the first one. It has long been known that reproductive performance and fertility in dairy cattle is influenced as much by nutrition as by genetic predisposition. ${ }^{16}$ There are also studies on the inclusion of fatty acids in ruminants in order to improve the composition of fatty acids in milk. This is especially important during the transition period and early lactation, when the animal is particularly sensitive to nutritional imbalances. In addition, many other milk modifications have been suggested to improve the nutritional quality of milk and it's processing into dairy. ${ }^{17}$ Other studies evaluated the effect of the feeding system on fatty acid composition, CLA content and relative candidate gene expression of genes involved in lipid metabolism in Rasa Aragonesa light lambs in semitendinous muscle. ${ }^{18}$ The effect of the feeding system was evaluated by applying an intensity gradient according to the use of concentrates: grazing alfalfa, grazing alfalfa with a supplement for lambs, indoor lambs with grazing ewes and dry lot. The results indicated that the feeding system is the main factor affecting the fatty acid composition and $\Delta 9$-desaturase gene expression, which is also affected by CLA and possibly by n-6/n-3 PUFAs in muscle.

\section{Studies of supplementation with vitamins}

There are other dietary additives such a vitamins (E,A, etc) that offer some potential to improve meat quality. Vitamin A is a wellknown regulatory factor involved in processes like immunity, vision, reproduction, growth, and development. ${ }^{19}$ The effect of vitamin $\mathrm{A}$ and its main active metabolite, retinoic acid, on cell growth and differentiation and their importance in adipose tissue biology, obesity, and type II diabetes have become apparent in recent years Ayuso et al. $^{20}$ studied the effect of different periods of dietary vitamin A restriction on carcass traits, IMF content, and fatty acid composition and gene expression in different tissues of Iberian pigs. Overall, the results showed the influence of a vitamin A-restricted diet on IMF content and on fatty acid profile, which may lead to a higher meat quality. Results found in this experiment show that long-term restriction of dietary vitamin A has a positive effect on nutritional and sensorial parameters of ham meat. Moreover, gene expression results were consistent with the vitamin A transcriptional regulation of adipogenesis and lipogenesis and with the changes observed in meat and fat composition, with the treatment significantly affecting the expression of lipogenic genes (SCD, ACOX1 and ACSL4), genes involved in the transcriptional control of adipogenesis (RXRG and CEBPB), vitamin A metabolism (CRABII) and regulation of energy homeostasis (CEBPB, INSR and IGF1). Feed supplementation with vitamin $\mathrm{E}$ (VE) is widely employed in the meat industry as a method to avoid adverse reactions in meat due to its antioxidant properties. Also in animal production, VE is extensively applied to improve growth, reproductive performance, feed efficiency and preferred meat product quality. A transcriptome study in broilers ${ }^{21}$ compared the genome wide gene expression profiles of breast muscle from chicks fed vitamin $\mathrm{E}$ and an algae-based antioxidant diets. This study found differential expression in transcriptional profiling between the two diets and identified gene networks that likely play key roles related to nutriphysiological functions of vitamin E. In a more recent study, ${ }^{20}$ different dietary supplementations with Vitamin E (VE) and different inclusion levels of grape pomace (GP) vs an un supplemented control group were compared to study their effects on the expression of candidate genes involved in oxidation and lipid metabolism in broiler muscle. Grape pomace has been proposed to improve the oxidative stability of meat due to its content in polyphenolic compounds. Supplementation with GP in broiler chicks does not affect performance, but has a protecting effect similar to VE, reducing susceptibility to lipid oxidation. The genes SCP2, HADH, HMOX and CAT were affected by the applied diets. The upregulation in both treated groups of genes related to oxidation (CAT) and lipid metabolism (SCP2 and $\mathrm{HADH}$ ) is in agreement with dietary effects on phenotype. HMOX2 and SOD1 gene expression differences observed between VE and GP are interesting findings, which suggest differential pathways of both supplements to induce antioxidant effects. The results might indicate a higher potential of polyphenols for controlling oxidative stress by means of heme-catabolism pathway, in comparison to VE and suggest biological mechanisms for VE and GP actions at both metabolic and antioxidant levels.

\section{Studies of supplementation with selenium}

Also, the effects of organic and inorganic dietary selenium 
supplementation on gene expression have been studied in swine, poultry and ruminants. In food animals, organic dietary Se can enhance milk yield, egg production and growth performance. ${ }^{22,23}$ Determined Juniper et al. ${ }^{24}$ the concentration of total selenium and the proportion of total (Se) comprised as selenomethionine and selenocysteine, as well as meat quality of lambs offered diets with an increasing dose rate of selenized enriched yeast or sodium selenite. The role of Se in reproductive performance in poultry seems to be dependent on both Se source and length of supplementation. Maintaining flocks on diets supplemented with organic Se for a long period of time $(12$ weeks +$)$ improves egg production in broilers ${ }^{22}$ and layers. ${ }^{23}$ This preliminary study is the first to establish a positive relationship between organic Se supplementation and the transcription of genes encoding energyassociated mitochondrial proteins and protein synthesis networks. These findings establish a platform for future research on the impact of Se on mitochondrial function and energy production. These studies have shown the value of such techniques and suggest that it will be possible to use specific gene expression patterns to evaluate the effects of nutrition on key metabolic processes relating to productive and reproductive performance. While the effects of nutrition on fertility are only partially understood, modern nutrigenomics will undoubtedly play a key role in developing strategies for addressing some of the limitations in reproductive performance. ${ }^{26-3}$

\section{Conclusion}

In conclusion, the results of the available experiments allow us to emphasize the importance of the influence of genetic-nutrition interactions on different physiological and metabolic processes with transcendence in animal production. The obtained information allows us to deepen in the knowledge of the genes and metabolic pathways affected by diet and the influence that the nutritional interventions can have on their regulation. On the other hand, the subsequent structural characterization of these genes and the identification of their allelic variation in animals present future implications of great interest both for genetic improvement of the breeds and for the understanding of the variability in the individual response to nutritional factors. This in turn may have future implications for the formulation of animal diets.

\section{Acknowledgements}

None.

\section{Conflict of interest}

Author declares that there is no conflict of interest.

\section{References}

1. Lopez IP, Marti A, Milagro FI, et al. DNA microarray análisis of genes differencially expressed in diet induced (cafeteria) obese rats. Obes Res. 2003;11(2):188-194.

2. Ordovas JM, Corella D. Nutritional Genomics. Аnnu Rev Genomics Hum Genet. 2004;5:71-118.

3. Hsu JM, Ding ST. Effect of polyunsaturated fatty acids on the expression of transcription factor adipocyte determination and differentiationdependent factor 1 and of lipogenic and fatty acid oxidation enzymes in porcine differentiating adipocytes. Br J of Nutr. 2003;90(3):507-513

4. Hamill R, Aslan MO, Mullen AM, et al. Transcriptome analysis of porcine $\mathrm{M}$. semimembranosus divergent in intramuscular fat as a consequence of dietary protein restriction. BMC Genomics. $2013 ; 14: 453$

5. Keller J, Ringseis R, Priebe S, et al. Dietary L-carnitine alters gene expression in skeletal muscle of piglets. Mol Nutr Food Res. 2011;55(3):419-429.
6. Muller M, Kersten S. Nutrigenomics: goals and strategies. Nat Rev Genet. 2003;4(4):315-322.

7. Andersen HJ, Oksbjerg N, Young JF, et al. Feeding and meat quality-A future approach. Meat Science. 2005;70(3):543-554.

8. Woods VB, Fearon AM. Dietary sources of unsaturated fatty acids for animals and their transfer into meat, milk and eggs: a review. Livestock Science. 2009;126(1-3):1-20.

9. Lopez-Bote C. XV Curso de specialización F.E.D.N.A. Avances en Nutrición y Alimentación animal. 1999. p. 225-252.

10. Jiang ZY, Zhong WJ, Zheng CT, et al. Conjugated linoleic acid differentially regulates fat deposition in backfat and longissimus muscle of finishing pigs. J Anim Sci. 2010;88 (5):1694-1705.

11. Benitez R, Nunez Y, Fernandez A, et al. Adipose tissue transcriptional response of lipid metabolism genes in growing Iberian pigs fed oleic acid v. carbohydrate enriched diets. Animal. 2016;10(6):939-946.

12. Ovilo C, Benitez R, Fernandez A, et al. Dietary energy source largely affects tissue fatty acid composition but has minor influence on gene transcription in Iberian pigs. J Anim Sci. 2014;92(3):939-954.

13. Benitez R, Nunez Y, Fernandez A, et al. Effects of dietary fat saturation on fatty acid composition and gene transcription in different tissues of Iberian pigs. Meat Science. 2015;102:59-68.

14. Joseph SJ, Robbins KR, Pavan E, et al. Effect of diet supplementation on the expression of bovine genes associated with Fatty Acid synthesis and metabolism. Bioinform Biol Insights. 2010;4:19-31.

15. Joseph SJ, Pratt SL, Pavan E, et al. Omega-6 fat supplementation alters lipogenic gene expression in bovine subcutaneous adipose tissue. Gene Regul Syst Bio. 2010;4:91-101.

16. Butler WR. Review: effect of protein nutrition on ovarian and uterine physiology in dairy cattle. J Dairy Sci. 1998;81(9):2533-2539.

17. Laible G. Enhancing livestock through genetic engineering-Recent advances and future prospects. Comparative Immunology Microbiology and Infectious Diseases. 2009;32(2):123-137.

18. Dervishi E, Serrano C, Joy M, et al. Effect of the feeding system on the fatty acid composition, expression of the $\Delta 9$-desaturase, Peroxisome Proliferator-Activated Receptor Alpha, Gamma, and Sterol Regulatory Element Binding Protein 1 genes in the semitendinous muscle of light lambs of the Rasa Aragonesa breed. BMC Vet Res. 2010;6:40.

19. Blaner WS, Olson JA. Retinol and retinoic acid metabolism. In: Sporn MB, editor. The retinoids: Biology, chemistry and medicine. 2nd ed. New York: Raven Press; 1994. p. 229-256.

20. Ayuso M, Fernandez A, Isabel B, et al. Long term vitamin A restriction improves meat quality parameters and modifies gene expression in Iberian pigs. J Anim Sci. 2015;93(6):2730-2744.

21. Xiao R, Power RF, Mallonee D, et al. A comparative transcriptomic study of vitamin $\mathrm{E}$ and an algae-based antioxidant as antioxidative agents: Investigation of replacing vitamin $\mathrm{E}$ with the algae-based antioxidant in broiler diets. Poult Sci. 2011;90(1):136-146.

22. Renema RA. Effects of dietary selenium source on egg production, fertility, hatchability and shell quality of broiler breeders. Poult Sci. 2003;82(Suppl 1):51.

23. Pavlovic Z, Miletic I, Jokic Z, et al. The effect of dietary selenium source and level on hen production and egg selenium concentration. Biol Trace Elem Res. 2009;131(3):263-270.

24. Juniper DT, Phipps RH, Ramos-Morales E, et al. Effects of dietary supplementation with selenium enriched yeast or sodium selenite on selenium tissue distribution and meat quality in lambs. $J$ Anim Sci. 2009;86(11):3100-3109.

25. Zhang HB, Wang ZS, Peng QH, et al. Effects of different levels of protein supplementary diet on gene expressions related to intramuscular deposition in early-weaned yaks. Anim Sci J. 2014;85(4):411-419. 
26. Liao SF, Brown KR, Stromberg AJ, et al. Dietary supplementation of selenium in inorganic and organic forms differentially and commonly alters blood and liver selenium concentrations and liver gene expression profiles of growing beef heifers. Biol Trace Elem Res. 2011;140(2):151-169.

27. Núñez Y, Fernandez A, Benitez R, et al. Dietary supplementation with Vitamin E or Grape pomace influences antioxidant and lipid metabolism candidate gene expression in broiler. 35th International Scoiety for Animal Genetics Conference (Utah, EEUU). 2016.

28. Sevane N, Bialade F, Velasco S, et al. Dietary inulin supplementation modifies significantly the liver transcriptomic profile of broiler chickens. PLoS One. 2014;9:e98942.
29. Pan YZ, Wu SG, Dai HC, et al. Solexa sequencing of microRNAs on chromium metabolism in broiler chicks. J Nutrigenet Nutrigenomics. 2013;6(3):137-153.

30. Brennan KM, Crowdusa CA, Cantorb AH, et al. Effects of organic and inorganic dietary selenium supplementation on gene expression profiles in oviduct tissue from broiler-breeder hens. Animal Reprod Sci. 2011;125(1-4):180-188.

31. Kim DK, Lillehoj HS, Lee SH, et al. High-throughput gene expression analysis of intestinal intraepithelial lymphocytes after oral feeding of carvacrol, cinnamaldehyde, or Capsicum oleoresin. Poult Sci. 2010;89(1):68-81. 